Ann. Biol. anim. Bioch. Biophys., 1979, 19 (5), 1399-1407

\title{
The initiation of oocyte growth in the mouse ovary
}

\author{
par Sue LINTERN-MOORE, G. P. M. MOORE *
}

\author{
School of Biological Sciences, Macquarie University \\ North Ryde, N.S.W., 2113 Australia. \\ * Ian Clunies Ross Animal Research Laboratory, \\ Division of Animal Production, C.S.I.R.O., \\ P.O. Box 239 Blacktown, N.S.W., 2184 Australia.
}

Summary. In prepuberal mouse ovaries oocytes in the non-growing pool show constant but low levels of DNA-dependent RNA polymerase activity. The first event in the initiation of oocyte growth is a marked stimulation of RNA polymerase activity in the oocyte nucleolus. This is followed by increases in oocyte area, oocyte nucleolar area, oocyte nuclear area and nucleoplasmic RNA synthesis in that sequence.

Non-growing oocytes may be surrounded by 2-8 follicle cells in the widest cross section. The progressive accumulation of follicle cells is marked by a transition from squamous to cuboidal morphology. The initiation of oocyte growth occurs at 9 follicle cells when the bulk ( 96 p. 100) of the follicular epithelium has become cuboidal. The transition from a squamous to cuboidal follicular epithelium is initiated at 5 follicle cells. The contribution of non-growing oocytes to the total oocyte pool declines from 15 p. 100 at 5 follicle cells to 2 p. 100 at 9 follicle cells. Mitotic division in follicular cells is only evident in follicles with more than 9 cells in the widest cross section. These results suggest that the accumulation of follicle cells becomes increasingly rapid as the oocyte approaches the initiation of growth.

The data define the primary event in the initiation of oocyte growth as a stimulation of nucleolar RNA synthesis and demonstrate that oocyte growth is only initiated in follicles with an almost completely cuboidal follicular epithelium. We propose that the stimulation of nucleolar RNA synthesis as the first event in the initiation of oocyte growth is in response to an inductive stimulus from the surrounding follicular cells.

\section{Introduction.}

So often we hear, read and use the term «initiation of follicular growth » in relation to the mammalian ovary. What do we mean when we use this descriptive expression? In general terms, of course, we understand it to mean the presence in the ovary of follicles recognisably and measurably larger than those in the so-called nongrowing pool laid down during perinatal life. By inference, therefore, follicle growth is known to have been initiated. We must then ask ourselves what we mean by the « non-growing follicle pool». Considerable confusion and ambiguity surrounds the definition of this limited stock of oocytes and their follicular epithelium. 
A cursory glance at the juvenile and adult ovarian cortex of any mammal shows the presence of oocytes of apparent minimal size surrounded by not only a variable number of follicle cells but also follicle cells which differ in morphology from squamous to cuboidal.

Pedersen and Peters (1968) in their proposal for a follicle classification for the mouse ovary circumvented this problem by referring to follicles containing a « non growing $\gg$ oocyte as small follicles surrounded by anything up to 20 follicle cells (types 2 and $3 a)$. Furthermore the pioneering studies of Pedersen $(1969,1970)$ of the dynamics of follicle growth in the mouse found that cells of small follicles did not label with ${ }^{3} \mathrm{H}$-thymidine in a manner consistent with cells of larger follicles and therefore were not amenable to comparable labelling index and transit time analyses.

We are therefore faced with the paradox that we have been attempting to understand the control of a developmental event which has never been adequately defined in quantitative terms yet which is central to the attainment of sexual maturity and fertility in all mammals.

In these studies we started with the simple proposition that the oocyte must undergo an obligatory period of growth (Brambell, 1928) and RNA synthesis (Moore and Lintern-Moore, 1974, 1978) before meiotic maturation can occur and that these parameter could be used to define the difference between the quiescent, non-growing oocyte laid down during perinatal life and an oocyte initiated to grow. Since oocyte growth is always accompanied by the enlargement of the follicular envelope and «naked» oocytes do not persist in the adult (Peters, 1969) we related the structural and functional status of the non-growing and growing oocyte to the number, morphology and area of the surrounding follicular cells together with the incidence of mitotic figures within the follicle cells.

The data presented define the structural and functional events in oocytes initiated to grow in the mouse ovary. These events when related to changes in the follicular envelope permit a description of the initial stages of follicular growth to be derived.

\section{Materials and methods.}

30 day old mice of the Quackenbush strain were used. Mice were maintained at $21^{\circ}$ (12 $\mathrm{h}$ light : $12 \mathrm{~h}$ dark) and allowed free access to water and commercial pelletted food.

Cryostat ovarian sections $(8 \mu \mathrm{m})$ from ovaries of 12 mice were prepared on a freezing microtome, picked up on gelatinized slides, fixed for $5 \mathrm{~min}$. in ethanol and acelone (1:1 by vol) and stored in the presence of a desiccant at $-15^{\circ}$.

The parameters used to monitor the structural and functional status of the oocyte and its follicular envelope in the non-growing and growing pool were : the area of the oocyte, the area of the oocyte nucleus, the area of the oocyte nucleolus, the transcriptional activity of the oocyte nuclear genome, the transcriptional activity of the oocyte nucleolar genome, the area of the follicular envelope, the number of cells in the widest cross section of the follicular envelope, the morphology of the follicle cells.

The areas of the above structures were computed by measuring the mean of the two diameters of the structure passing through the widest cross section of the oocyte 
containing the oocyte nucleolus. Follicles were classified according to the number of follicle cells present in the widest cross section. 25 follicles were scored for the structural and functional parameters of the oocyte in each follicular compartment with 2, 3,4, 5,6 etc... up to 25 follicle cells in the widest cross section. The morphology of each follicle cell and the area of the follicle envelope were also recorded. The number of mitotic figures in these follicle cells was counted. The transcriptional activities of the oocyie nuclear and nucleolar genes were measured using a cytochemical assay for RNA polymerase (Moore, 1978 ; Moore and Lintern-Moore, 1978, 1979). RNA incorporating ${ }^{3} \mathrm{H}$-UMP was quantitated by grain density autoradiography. The nucleolar or nucleoplasmic localizations of grains distinguished between Polymerase I and Polymerase II activities respectively.

The results of this study clearly delineated the characteristics of oocytes initiated to grow and the accompanying status of the follicular envelope. In order to determine the percentage of the total oocyte population initiated to grow and the distribution of nongrowing oocytes in relation to the accumulation of follicle cells serial paraffin sections of ovaries from $530 \mathrm{~d}$ old Quackenbush mice were prepared and stained with haematoxylin and eosin. Standard counts fo follicles were made according to Zuckerman (1951). The follicle classification used was that of Pedersen and Peters (1968) with the modification that non-growing oocytes were partitioned into those surrounded by $2,3,4,5,6,7$ and 8 follicle cells and growing oocytes into those surrounded by 9 follicle

TABLE 1

Changes In the area of the follicular envelope, oocyte, oocyte nucleus and oocyfe nucleolus $\left(\mu \mathrm{m}^{2}\right)$ (mean $\pm \mathrm{SEM}$ ) with follicle cell number. 25 follicles scored per follicle growth stage. $* P<0.05$

\begin{tabular}{|c|c|c|c|c|}
\hline $\begin{array}{l}\text { Number of } \\
\text { Follicle cells }\end{array}$ & $\begin{array}{l}\text { Follicle } \\
\text { Area }\end{array}$ & $\begin{array}{l}\text { Oocyłe } \\
\text { Area }\end{array}$ & $\begin{array}{c}\text { Nuclear } \\
\text { Area }\end{array}$ & $\begin{array}{c}\text { Nucleolar } \\
\text { Area }\end{array}$ \\
\hline $\begin{array}{r}2 \\
3 \\
4 \\
5 \\
6 \\
7 \\
8 \\
9 \\
10 \\
11 \\
12 \\
13 \\
14 \\
15 \\
16 \\
17 \\
18 \\
19 \\
20 \\
21 \\
22 \\
23-25\end{array}$ & $\begin{array}{r}50 \pm 13 \\
94 \pm 15 \\
164 \pm 23 \\
170 \pm 14 \\
180 \pm 15 \\
230 \pm 25 \\
263 \pm 17 \\
305 \pm 42 \\
366 \pm 62 \\
471 \pm 72 \\
419 \pm 63 \\
445 \pm 94 \\
468 \pm 47 \\
481 \pm 71 \\
870 \pm 93 \\
711 \pm 113 \\
745 \pm 76 \\
829 \pm 78 \\
876 \pm 79 \\
1122 \pm 121 \\
964 \pm 87 \\
1315 \pm 140\end{array}$ & $\begin{array}{c}220 \pm 38 \\
240 \pm 18 \\
216 \pm 12 \\
211 \pm 11 \\
202 \pm 12 \\
254 \pm 25 \\
245 \pm 19 \\
322 \pm 31 \\
352 \pm 49 * \\
422 \pm 46 \\
425 \pm 54 \\
549 \pm 173 \\
500 \pm 58 \\
558 \pm 62 \\
680 \pm 52 \\
631 \pm 61 \\
748 \pm 109 \\
857 \pm 70 \\
810 \pm 48 \\
948 \pm 99 \\
879 \pm 109 \\
1339 \pm 112\end{array}$ & $\begin{array}{r}73 \pm 11 \\
76 \pm 5 \\
71 \pm 5 \\
65 \pm 3 \\
71 \pm 3 \\
74 \pm 6 \\
72 \pm 4 \\
89 \pm 7 \\
87 \pm 14 \\
99 \pm 14 \\
99 \pm 11 \\
109 \pm 20 * \\
93 \pm 7 \\
96 \pm 7 \\
126 \pm 11 \\
105 \pm 15 \\
111 \pm 16 \\
112 \pm 15 \\
112 \pm 10 \\
120 \pm 11 \\
110 \pm 12 \\
156 \pm 12\end{array}$ & $\begin{array}{r}5 \pm 1 \\
5 \pm 1 \\
5 \pm 1 \\
5 \pm 0 \\
5 \pm 0 \\
5 \pm 0 \\
4 \pm 0 \\
6 \pm 1 \\
6 \pm 1 \\
8 \pm 1 \\
7 \pm 1 \\
6 \pm 1 \\
7 \pm 1 \\
8 \pm 1 \\
9 \pm 1 \\
10 \pm 1 \\
8 \pm 2 \\
8 \pm 1 \\
10 \pm 1 \\
8 \pm 1 \\
6 \pm 1 \\
9 \pm 1\end{array}$ \\
\hline
\end{tabular}


cells (the point of initiation of oocyte growth) with type $3 a$ commencing at 10 follicle cells. Statistical significance was tested using Student's t-test (Miller, 1966).

\section{Results.}

Non-growing oocytes were surrounded by between 2 and 8 follicle cells in the widest cross section. The first event in the initiation of oocyte growth was a marked increase in the activity of DNA dependent RNA polymerase I activity in the oocyte nucleolus at 9 follicle cells. Oocyte area increased at 10 follicle cells followed by sequential increases in oocyte nucleolar area, oocyte nuclear area and oocyte nucleoplasmic RNA synthesis (tables 1 and 2).

\section{TABLE 2}

Changes in the incorporation of ${ }^{3} \mathrm{H}$-UMP as measured by the number of silver grains (mean $\pm \mathrm{SEM}$ ) over the oocyte nucleoplasm and nucleolus with increasing follicle cell number. ${ }^{*} \mathrm{P}<0.05$

\begin{tabular}{ccc}
\hline $\begin{array}{c}\text { Number of } \\
\text { Follicle Cells }\end{array}$ & $\begin{array}{c}\text { Nucleoplasmic } \\
\text { Grain } \\
\text { Number }\end{array}$ & $\begin{array}{c}\text { Nucleolar } \\
\text { Grain } \\
\text { Number }\end{array}$ \\
\hline 2 & $10 \pm 2$ & \\
\hline 3 & $11 \pm 3$ & $13 \pm 3$ \\
4 & $9 \pm 1$ & $15 \pm 2$ \\
5 & $8 \pm 1$ & $13 \pm 3$ \\
6 & $9 \pm 1$ & $14 \pm 1$ \\
7 & $12 \pm 1$ & $11 \pm 1$ \\
8 & $10 \pm 2$ & $15 \pm 1$ \\
9 & $9 \pm 1$ & $15 \pm 2$ \\
10 & $12 \pm 2$ & $23 \pm 3 *$ \\
11 & $17 \pm 3$ & $21 \pm 3$ \\
12 & $14 \pm 4$ & $23 \pm 2$ \\
13 & $16 \pm 1$ & $23 \pm 3$ \\
14 & $12 \pm 2$ & $23 \pm 3$ \\
15 & $18 \pm 3$ & $23 \pm 3$ \\
16 & $20 \pm 2 *$ & $26 \pm 4$ \\
17 & $18 \pm 1$ & $26 \pm 5$ \\
18 & $22 \pm 3$ & $25 \pm 4$ \\
19 & $21 \pm 3$ & $21 \pm 2$ \\
20 & $25 \pm 2$ & $24 \pm 4$ \\
21 & $20 \pm 3$ & $27 \pm 4$ \\
22 & $25 \pm 4$ & $23 \pm 3$ \\
$23-25$ & $24 \pm 4$ & $24 \pm 4$ \\
& & \\
\hline
\end{tabular}

Throughout both the non-growing and growing phases of the oocyte the number of follicle cells and the area of the follicular envelope increased and changed in morphology (table 3). From 2-4 follicle cells the cell morphology was predominantly squamous. At 5 follicle cells a significant transition occurred to include at least one cuboidal follicle cell in the follicular envelope. Thereafter the number of squamous cells declined and the number of cuboidal cells increased reaching 100 p. 100 at 12 follicle cells. At 9 follicle cells, the point of initiation of oocyte growth, 68 p. 100 of follicles 
surveyed were surrounded by a totally cuboidal epithelium. Of the total number of follicle cells scored in this follicular category 96 p. 100 were found to be cuboidal. In follicles with between 2 and 9 cells in the widest cross section the mitotic index of 9,740 cells surveyed was not significantly different from zero. Mitotic figures first appeared at 10 follicle cells.

TABLE 3

The percentage of oocytes surrounded by a squamous $(S)$ mixed ( $M$, squamous plus one or more cuboidal) or cuboidal (C) follicular epithelium and the percentage of squamous $\left(\mathrm{S}^{\prime}\right)$ or cuboidal $\left(\mathrm{C}^{\prime}\right)$ cells contributing to the total number of follicle cells surveryed at each increase in follicle cell number.

\begin{tabular}{crrrrr}
\hline $\begin{array}{c}\text { Follicle } \\
\text { Cell } \\
\text { Number }\end{array}$ & \multicolumn{5}{c}{ Percentage } \\
\cline { 2 - 6 } & $\mathrm{S}$ & $\mathrm{M}$ & $\mathrm{C}$ & $\mathrm{S}^{\prime}$ & $\mathrm{C}^{\prime}$ \\
\hline 2 & 100 & 0 & 0 & 100 & 0 \\
3 & 95 & 5 & 0 & 93 & 7 \\
4 & 84 & 16 & 0 & 91 & 9 \\
5 & 8 & 92 & 0 & 67 & 33 \\
6 & 0 & 100 & 0 & 40 & 60 \\
7 & 0 & 88 & 12 & 22 & 78 \\
8 & 0 & 76 & 24 & 22 & 78 \\
$9\left({ }^{2}\right)$ & 0 & 32 & 68 & 4 & 96 \\
10 & 0 & 36 & 64 & 4 & 96 \\
11 & 0 & 16 & 84 & 1 & 99 \\
12 & 0 & 0 & 100 & 0 & 100 \\
13 & 0 & 0 & 100 & 0 & 100 \\
14 & 0 & 0 & 100 & 0 & 100 \\
15 & 0 & 0 & 100 & 0 & 100 \\
& & & & & \\
\hline
\end{tabular}

(1) Number of follicle cells in the widest cross section.

$\left({ }^{2}\right)$ The initiation of oocyte growth.

The distribution of non-growing oocytes within the follicular growth compartments of 2-8 follicle cells, 9 follicle cells and thereafter expressed as a percentage of the total number of follicles per ovary is presented in figure 1 . At $30 \mathrm{~d}$ of age only 2 p. 100 of all oocyles were initiated to grow. Oocytes surrounded by 2-4 follicle cells comprised 52 p. 100 of the total follicle population. The proportion of the total oocyte population represented by non-growing oocyles thereafter declined as the accumulation of follicle cells increased from 5 to 9 cells in the widest cross section.

\section{Discussion.}

A clear delineation exists between non-growing oocytes and those initiated to grow towards ovulation. In the ovaries of $30 \mathrm{~d}$ old Quackenbush stain mice we first detected the initiation of oocyte growth as a marked increase in oocyte nucleolar RNA synthesis. Increases in oocyte area, oocyte nucleolar area, oocyte nuclear area, and nucleoplasmic RNA synthesis then followed. Since these oocytes have been quiescent since their formation some 30 days earlier this response is similar to that of other quies- 
cent cells initiated to resume growth. It has been suggested (Van Blerkom and Brockway, 1975) that resumption of growth may be dependent on the availability of ribosomal RNA which is synthesized in the nucleolus. Such changes in RNA synthesis characterise cells initiated to grow. A marked rise in ribosomal RNA is typical of target cells following hormone administration (Tata, 1968). These data supported by the sequential increases found in the other growth parameters of the oocyte demonstrate that a non-growing oocyte may be precisely distinguished from one initiated to grow.

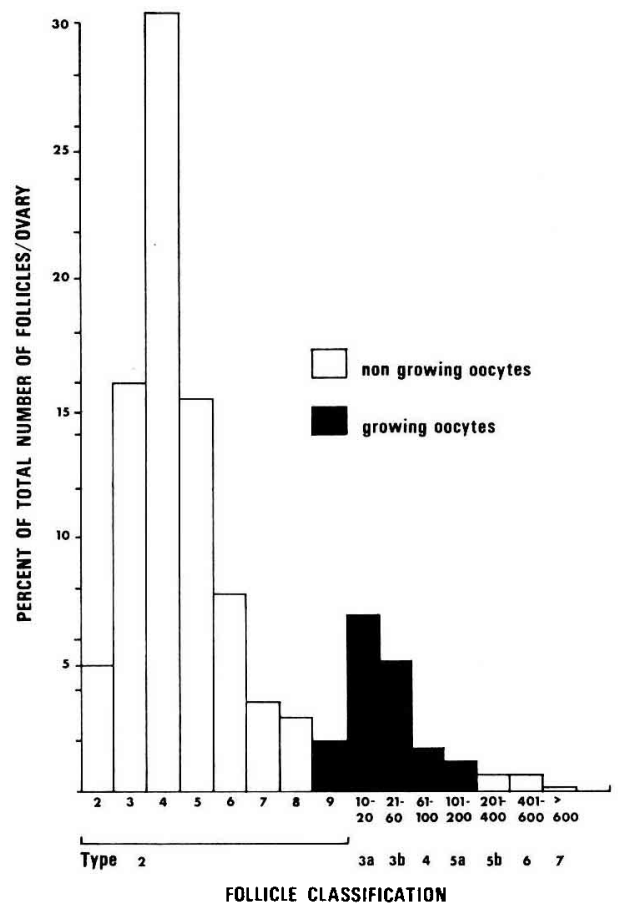

FIG. 1. - The distribution of oocytes (mean \pm SEM) expressed as a percentage of the total number of oocytes per ovary through the follicular growth compartments.

The definition of the initiation of follicular growth presents greater difficulties. Throughout the non-growing phase of the oocyte follicle cells are accumulated (tables 1 and 2). With increasing number, follicle cells progress from a squamous to cuboidal type. The word accumulate is chosen deliberately since mitotic figures were not detected in follicle cells until 10 cells were present in the widest cross section.

Clear evidence has been presented to show that follicle cells in the peri-natal mouse arise from the rete ovarii (Byskov and Lintern-Moore, 1973 ; Byskov, 1975). An earlier study of Peters and Pedersen (1967) suggested that follicle cells in infant mice originate from the ovarian stroma. The present data support both views that the growth of follicles prior to the initiation of oocyte growth is through the accumulation of a stromal stem cell population possibly of rete ovarian origin. So 2 categories of nongrowing oocytes may be distinguished. Those surrounded by 2-4 predominantly 
squamous cells and those surrounded by 5-8 cells which include an increasingly cuboidal component which reaches 96 p. 100 in oocytes initiated to grow at 9 cells. The transition from the squamous to cuboidal is heralded at 5 follicle cells. We suggest that those oocytes surrounded by $2-4$ follicle cells might be justifiably termed « primordial follicles ». Thereafter follicles with 5 to 8 cells in the widest cross section should be included in the growing follicle compartment. The declining number of non-growing oocytes as follicle cell number increases from 5 cells to 8 cells suggests that follicle growth through these compartments becomes increasingly more rapid as cell number increases.

This definition of non-growing and growing follicles has been applied (fig. 2) in a recent study of the effects of PMSG on the initiation of follicular growth in the mouse (Lintern-Moore, 1978). Newborn mice treated from birth to 5 or 10 days of age with PMSG showed a significant increase in the number of follicles containing one or more cuboidal cells. This was not evident in mice treated from days 5 to 10 of life. Previous studies using coarser definitions of ovarian responsiveness failed to demonstrate the ability of the infant ovary to react to exogenous gonadotrophin (Price and Ortiz, 1944 ; Ben Or, 1963 ; Peters et al., 1973).

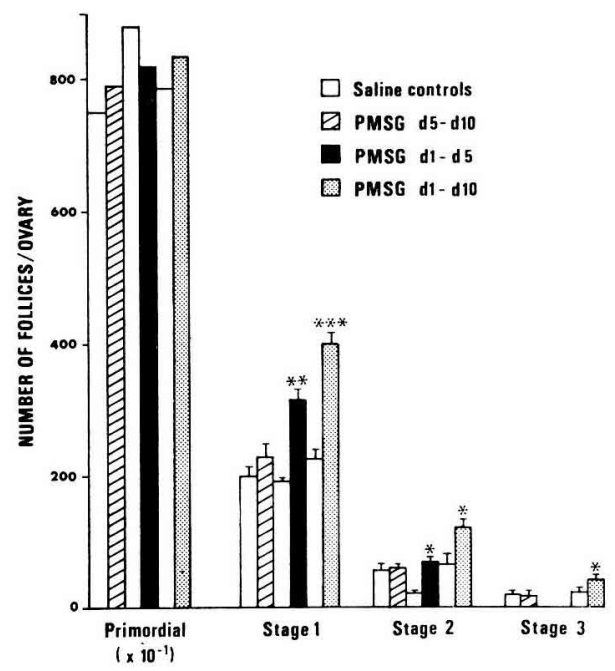

FIG. 2. - The effect of Pregnant Mare Serum Gonadotrophin (PMSG) (2 i.u. per day) on the number of ovarian follicles (mean \pm SEM) initiated to grow in infant Outbred Strain mice. Saline or PMSG was administered to 5 mice in each group from birth until 5 days of age or from birth until 10 days of age. An additional 4 mice received PMSG from day 5 to day 10 of life. The initiation of follicular growth was defined as the presence of one cuboidal follicle cell in the follicular epithelium $* P<0.05 ; * * P<0.01 ; * * * P<0.001$ (Lintern-Moore, 1978).

In the present study the close correlation between the accumulation of an almost totally cuboidal follicular epithelium and the initiation of oocyte growth suggests a role for the cuboidal follicle cells in the reactivation of the oocyte genome. We propose that a stimulation of nucleolar RNA synthesis as the first event in the initiation of oocyte growth is in response to an inductive stimulus from the surrounding follicular 
cells. These definitions are now being used to investigate the age-dependent sequential control of the initiation of oocyte growth in the mouse and the endocrine (intra-or extra-ovarian) contribution to this event.

\section{Conclusion.}

In 30 day old ovaries from Quackenbush strain mice only 2 p. 100 of the total oocyte population are initiated to grow. The first event in the initiation of oocyte growth was a significant increase in DNA dependent RNA polymerase activity in the oocyte nucleolus. The initiation of oocyte growth was only detected in oocyles surrounded by a predominantly cuboidal follicular epithelium. The strong correlation between the accumulation of a cuboidal epithelium and stimulation of the oocyte genome leads us to conclude that oocyte growth may be induced by a stimulus from the surrounding follicle cells.

EEC Seminar on "Ovarian stimulation and egg quality in mammals ». Luynes, France, octobre 1978.

Acknowledgements. - This study was supported in part by a Research Grant to SL-M from the Clive and Vera Ramaciotti Foundations, Australia.

Résumé. Dans les ovaires de souris prépubère, les ovocytes de la réserve des follicules qui ne sont pas en croissance montrent des niveaux constants mais bas d'activité ARN polymérase dépendante de l'ADN. Le premier événement de l'initiation de la croissance de l'ovocyte est une stimulation marquée d'activité ARN polymérase dans le nucléole de l'ovocyte. Ceci est suivi par des augmentations de la taille de l'ovocyte, de celles du nucléole, et du noyau de l'ovocyte et d'une synthèse d'ARN nucléoplasmatique dans cette séquence.

Les ovocytes au repos peuvent être entourés par 2 à 8 cellules folliculeuses en section transversale de la plus grande dimension. L'accumulation progressive des cellules du follicule est marquée par une transition morphologique de passage d'un état squameux à un état cuboïde. L'initiation de la croissance de l'ovocyte survient au stade 9 cellules du follicule quand la majorité ( 96 p. 100) de l'épithélium folliculaire devient cuboïde. Le passage transitoire de l'épithélium squameux à l'épithélium folliculaire cuboïde commence au stade 5 cellules du follicule. La contribution des ovocytes non en croissance au pool total d'ovocytes diminue de 15 p. 100 pour les follicules à 5 cellules à 2 p. 100 pour les follicules à 9 cellules. La division mitotique des cellules folliculeuses n'est seulement évidente que dans les follicules à plus de 9 cellules dans la plus grande section transversale. Ces résultats suggèrent que l'accumulation des cellules du follicule devient rapidement croissante alors que l'ovocyte approche du début de son développement.

Ces données définissent l'événement de début de la croissance de l'ovocyte comme étant une stimulation de la synthèse d'ARN nucléolaire et démontrent que la croissance de l'ovocyte ne commence uniquement que dans les follicules avec un épithélium folliculaire presque complètement cuboïde. Nous proposons que la stimulation de la synthèse d'ARN nucléolaire, premier événement de l'initiation de la croissance de l'ovocyte, soit une réponse à un stimulus inductif provenant des cellules folliculeuses environnant l'ovocyte.

\section{References}

BEN OR S., 1963. Morphological and functional development of the ovary of the mouse. J. Embryol. esp. Morph., 11, 1-11.

BRAMBELL F. W. R., 1928. The development and morphology of the gonads of the mouse. Part III. The growth of follicles. Proc. roy. Soc. B., 103, 258-271. 
BYSKOV A. G., 1975. The role of the rete ovarii in meiosis and follicle formation in the cat, mink and ferret. J. Reprod. Fertil., 45, 201-209.

BYSKOV A. G., LINTERN-MOORE S., 1973. Follicle formation in the immature mouse ovary : the role of the rete ovarii. J. Anat., 116, 207-227.

LINTERN-MOORE S., 1978. Initiation of follicular growth in the infant mouse ovary by exogenous gonadotrophin. Biol. Reprod., 17, 635-639.

MILLER R. G., 1966. Simultaneous statistical inference. McGraw and Hill.

MOORE G. P. M., 1978. RNA synthesis in fixed cells by endogenous RNA polymerases. Expt. Cell Res., 111, 317-326.

MOORE G. P. M., LINTERN-MOORE S., 1974. A correlation between growth and RNA synthesis in the mouse oocyte. J. Reprod. Ferfil., 39, 163-166.

MOORE G. P. M., LINTERN-MOORE, S., 1978. Transcription of the mouse oocyte genome. Biol. Reprod., 18, 865-870.

MOORE G. P. M., LINTERN-MOORE S., 1979. Patterns of gene activity during ovum formation in the mouse. Ann. Biol. anim. Bioch. Biophys., 19, 1409-1417.

PEDERSEN T., 1969. Follicle growth in the immature mouse ovary. Acta endocrinol., 62, 117-132.

PEDERSEN T., 1970. Follicle kinetics in the ovary of the cyclic mouse. Acta endocrinol., 64, 304-323.

PEDERSEN, T., PETERS H., 1968. Proposal for a follicle classification of oocytes and follicles in the mouse ovary. J. Reprod. Fertil., 17, 555-557.

PETERS H., 1969. The development of the mouse ovary from birth to maturity. Acta endocrinol., 62, 98-116.

PETERS H., BYSKOV A. G., LINTERN-MOORE S., FABER M., ANDERSEN M., 1973. The effects of gonadotrophin on follicle growth initiation in the neonatal mouse ovary. J. Reprod. Fertil., 35, 139-141.

PETERS H., PEDERSEN T., 1967. Origin of follicle cells in the infant mouse ovary. Fertil. Steril., 18, 309-313.

PRICE D., ORTIZ E., 1944. The relation of age and reactivity to the reproductive system of the rat. Endocrinology, 34, 215-239.

TATA J. R., 1968. Hormonal regulation of growth and protein synthesis. Nature (London), 219, 331337.

VAN BLERKOM J., BROCKWAY G. O., 1975. Qualitative patterns of protein synthesis in the preimplantation mouse embryo, Dev. Biol., 46, 446-451.

ZUCKERMAN S., 1951. The number of oocytes in the mature ovary. In PINCUS G., Recent Progr. Hormone Res., 6, 63-109. 